\title{
How Does the Market Price Responsible and Sustainable Investments?*
}

\author{
Barnabás Timár
}

In my study, I investigate whether it is possible to prove the hypothesis that investing in responsible, sustainable companies can be financially more rewarding from the perspective of investors, i.e. can result in higher profit than investing in companies that ignore these aspects. My further assumption is that this profit can be increased if I apply different restrictions or relative scores. I tested my hypotheses empirically on data from the New York Stock Exchange, both on investment strategies (portfolio creation) and at stock level (regression). I performed the tests for the total market, in detailed industry breakdowns and groupings as well. I tested the examined indicators (ESG, ENV) in isolation and with a relative approach, over several time horizons. For most of the tests, I obtained non-significant results; for some industries a minor negative impact can be seen, and for the regressions I obtained coefficients that are significant, but of negligible economic significance. Temporal decomposition shows the increasing significance of ESG and ENV, but even for the later time series it is not considered significant. The results suggest that the aspects under investigation are not yet priced by the market, so my hypotheses were not confirmed. This could be due to the greenwashing phenomenon or the developed US market.

Journal of Economic Literature (JEL) codes: G17, G32, G41

Keywords: Fama-French, ESG, ENV, environmental protection, factor, sustainability, return, US, stock exchange

\section{Introduction}

Nowadays, responsible and sustainable investment is increasingly important and popular (Kuzmina - Lindemane 2017). Growth and profit no longer preclude environmental protection (Németh-Durkó 2019). Corporate management has also recognised the importance of environmental consciousness and sustainability (Bank 2018; Ransburg - Vágási 2011). The ESG score is commonly used to measure

* The papers in this issue contain the views of the authors which are not necessarily the same as the official views of the Magyar Nemzeti Bank.

Barnabás Timár is an Undergraduate Student at the Corvinus University of Budapest.

Email: barnabas.timar@stud.uni-corvinus.hu

The first version of the study was prepared for the 'Green Finance' research competition organised by the Corvinus University of Budapest MNB Institute and the Institute of International, Political and Regional Studies, where it won 1st place.

The Hungarian manuscript was received on 15 September 2020.

DOI: http://doi.org/10.33893/FER.20.2.117147 
this (Townsend 2020). ESG is composed of three pillars: ${ }^{1}$ the environment and its protection (environmental; hereinafter ENV), social and corporate governance criteria (governance). The score measures compliance with the criteria, so it can be used to measure sustainability. In my study, I consider ESG and ENV as an appropriate approximation of responsible and sustainable investments, as these indices are basically designed for this purpose, but, of course, this approach also has shortcomings and can be criticised (see Kotsantonis - Serafeim 2019). Nevertheless, following the international literature, I also view this value as normative (Auer Schuhmacher 2016). Its growing importance can be seen from the fact that while in the 1990s only a few companies disclosed their ESG score, today, thousands of companies do so regularly (Kotsantonis et al. 2016). Responsible behaviour can bring a number of benefits to a company, for example, it can provide a competitive advantage in labour, product or capital markets (Kotsantonis et al. 2016). Using ESG, several studies have examined the impact of responsible management on a given company. Buallay (2019) finds that the indicator can also affect firm performance, $\mathrm{ROE}^{2}$ and $\mathrm{ROA}^{3}$. Similar results are obtained by Deák and Hajdu (2011), who find that enterprises with a positive assessment of environmental performance have higher ROE. Gillan et al. (2010) provide evidence of increased efficiency, and Kotsantonis et al. (2016) report a lower cost of capital for companies with higher ESG. This suggests that it makes financial sense for a company to strive for sustainable operation.

Another side of the question is whether investing in responsible and sustainable companies can be financially rewarding from the perspective of investors. My study focuses on this question and seeks to answer it. The explanation of returns has been a topic of interest for financial researchers for many years, and several theories have been put forward. The best-known theory since the 1960s is the Capital Asset Pricing Model (CAPM). This theory offers a comprehensive model to explain the expected returns. However, it has been subject to numerous criticisms, and many have shown that it does not work well in practice (Berlinger - Walter 1999; Fama - French 1996; Lai-Stohs 2015; Fernandez 2015). This has led to the development of factor models, which use other factors to try to forecast expected returns more accurately. Fama and French (1992) can be considered the creators of factor models, but before them, others also carried out similar studies (on market anomalies). Factor models are now able to explain returns in a statistically significant way and are accepted today (Fain - Naffa 2019). Carhart's (1997) four-factor model can be taken as a basis, in which he uses CAPM beta, size (market capitalisation), book-tomarket ratio and momentum to explain returns.

\footnotetext{
${ }^{1}$ See Subchapter 1.1. for more details.

${ }^{2}$ Return on equity

${ }^{3}$ Return on assets
} 
In my study, I examine in detail the relationship between responsible and sustainable management (ESG and ENV) and future stock returns. I test ESG and ENV, among other things, as a possible factor for forecasting returns, thereby examining the profitability of the strategy. The underlying assumption is that investors find it more valuable, and reward responsible and sustainable management. This is reflected in stock prices as well and hence in returns (Hassel - Semenova 2013). Another possibility is that the market is sensitive to outlier scores, and thus, for example, it penalises particularly polluting companies with unfavourable pricing. One method used to investigate the relationship is to analyse a trading strategy that sells lowscoring stocks and buys high-scoring ones, thus providing a comprehensive picture, whatever the relationship between the ESG and the returns might be. I also examine the relationship, using Fama-MacBeth regression (see Fama - McBeth 1973), controlling for several factors. I perform the analysis on the stocks of the New York Stock Exchange, looking at the total market and using detailed industry breakdown and industry grouping. I conduct the tests for both the ESG and the environmental component of ESG (ENV) separately and also take a novel approach by testing relative ESG and relative ENV, which examines the deviation from the industry mean. My proposed hypothesis is that investing in companies with responsible and sustainable management can result in higher profit than investing in companies that ignore these aspects. An additional hypothesis is that this profit can be increased if I apply different restrictions or relative scores.

The existing literature is divided on this topic, as several studies have been done with different results. Verheyden et al. (2016) find a positive relationship when dropping the worst-scoring firms from the portfolio (10 per cent of the total), but can only show a positive impact for risk-adjusted returns. The research by LandiSciarelli (2019) examines Italy and finds no positive relationship when using different ESG criteria in portfolio creation. Torre et al. (2020) find no relationship between ESG and the returns of the major European stocks, even when using several ESG indicators. Maiti (2020) concludes that with the use of ESG a better-performing model than the Fama - French (1992) three-factor model can be constructed. Here, however, the focus is more on risk and its management; and again, the results hold true for the risk-weighted return. Halldórsdóttir (2020) uses the event study methodology to investigate the relationship between ESG and returns with regard to Covid-19. She concludes that ESG has no impact on the US market. Jain et al. (2019) look at a number of major markets around the world, seeking to answer the question of whether sustainability indicators can be used to achieve higher returns. Their finding is that the use of conventional as well as responsible and sustainable methods leads to similar returns. According to Kumar et al. (2016), while ESG may not have an impact on returns, the price volatility of firms with a good score is significantly lower. A study by Khan (2019) constructs a model that takes into account the ESG score in the investment process and concludes that there 
may be value in ESG for investors. In their study, Sahut and Pasquini-Descomps (2015) examine the United States, Switzerland and the United Kingdom over the period 2007-2011 and find ESG to be significant only for the United Kingdom. Auer - Schuhmacher (2016) conduct a global study at the industry level, in which they find no difference between market and ESG portfolio performance in the US and Asia-Pacific markets. In Europe, however, it can be seen that investors pay a premium for responsible investments. Kumar (2019) reports in his study that the ESG has no additional information content compared to the factor models for the European market. Aouadi - Marsat (2018) examine the impact of ESG on the market value of companies at the international level between 2002 and 2011. Their conclusion is that it has no direct impact on it. Buallay (2019) examines the impact of ESG on US banks between 2007 and 2016 and finds a significant impact on market performance. A study by Maiti (2020) finds ESG to be a suitable risk management factor. Gloßner (2017) and Landi - Sciarelli (2019) find a negative relationship. These issues have also been addressed in the case of investment funds, and ESG funds generally perform better here (Wimmer 2013; Henke 2016; Bóta 2014). Also important is the conclusion of Halbritter-Dorfleitner (2015), according to which a number of factors can influence the results, such as the time horizon, the industry, the score calculation method and the database from which the data is derived. In areas where there is no consensus in the academic literature, further research is certainly worthwhile. This paper adds value to the existing literature, as it presents the results of a more detailed, comprehensive study of the US market by examining a longer time horizon and more time periods, and by applying several constraints and restrictions to ensure the analysis and robustness of the results.

\subsection{Indices of responsible and sustainable investments (ESG and ENV)}

Today, there are many indices of responsible and sustainable investment. Among them, ESG is one of the most effective and widely used (Talan - Sharma 2019). As noted above, the ESG indicator is composed of three pillars: environment and its protection (environmental), social criteria (social) and corporate governance criteria (governance). The three pillars can be considered individually, on their own merits, but it is common to consider them together as ESG; this allows us to obtain a comprehensive picture of how well a company is following the expected guidelines and how sustainable the investment is (Ribando - Bonne 2010). The environmental pillar includes the company's relationship with nature, its energy use, waste management, pollutant emissions, use of renewable energy and potential environmental risks. Thus, the ENV pillar is an effective index of sustainable investment (Van Duuren et al. 2016). Social criteria assess how a company interacts with employees, suppliers, customers and the related communities. The corporate governance pillar examines whether the management really represents the interests of shareholders, how the board function (is it sufficiently diverse and independent? 
are its members suitably experienced?) and whether the company has adequate internal regulations to avoid illegal activities and fraud.

Furthermore, ESG is an increasingly popular indicator among investors, which enables them to assess companies. More and more investment funds and brokerages offer ESG-based investments. A study by the US SIF Foundation (2018) shows that investors in the USA hold nearly USD 12 trillion in ESG-based investments, and this number is growing dynamically. The ESG indicator can be calculated in several ways and measured on different scales. In my study, I use the scale of 100 published by Thomson Reuters (Ribando - Bonne 2010), as it is one of the most widely used and provides the necessary nuance for the application of statistical methods ( $L i$ - Polychronopoulos 2020). In the market being studied, this indicator is available in the case of most companies. Another advantage is that it can be accessed from the same database as the other data I use, which reduces the possibility of data errors. In addition to specific scores, other criteria and expectations can also be set, such as exposure to coal or the military industry or avoidance of companies involved in workplace discrimination scandals. This can be of help in finding truly responsible companies and in making sustainable investment decisions, but I will leave that aside for now. Due to its definition, ESG is an excellent index of responsible and sustainable management, and thus suitable for the studies to be carried out. Climate change and other factors are making environmental protection and specifically green investments increasingly significant, and thus in this study I examine not only ESG, but also the ENV pillar individually, due to its growing significance.

\section{The methodology used}

The tests presented in this study are based on the methodology used in the literature for testing new factors (Mérö et al. 2019). I use two important testing tools: the investment strategy analysis with the univariate sort and the individual stock-level analysis with the Fama-MacBeth regression.

\subsection{Investment strategy analysis}

A common method in the academic literature for testing the effect of a given variable is the univariate sort. This is a testing of the returns of a trading strategy that, according to a given variable, buys high-value stocks and sells those of lowvalue. To test the returns of the strategy, I first sort the stocks by ESG or ENV value for each month. Then, I sort them into quantiles to create portfolios. Where the element number of the sample allows, I also perform a decile-based and tercilebased test (Fama - French 1992). Based on that, I calculate portfolio returns both in equal- and in value (market-capitalisation-) weighted form to correct for possible 
biases (Csillag - Neszveda 2020). With equal weighting, the investment ratio is the same for all stocks in the portfolio. In the case of weighting by value, the investment is made in proportion to the market share of the company in question, which is necessary to test robustness. Finally, I take the mean of the monthly portfolio returns to obtain an approximation of their expected value. As for the return of the investment strategy, I calculate it by subtracting the bottom-quantile return from the return of the portfolio containing the top quantile. Thus, in the trading strategy under consideration, the portfolio with the lowest value is basically sold, while the one with the highest value is bought each month. I test the significance of the resulting return by using the corrected t-statistics developed by Newey West (1987). This method corrects for fundamental biases such as autocorrelation or heteroskedasticity and provides much more robust results. I consider the usual significance levels of 10, 5 and 1 per cent authoritative for the tests.

The univariate sort is relatively simple and easy to interpret, but on its own it can give misleading results in some cases. Its advantage is that we do not need to make any assumptions whatsoever about the relationship between the variable being tested and the return. Its disadvantage is that we can only look at one factor at a time and thus may capture another effect. This needs to be checked by further control tests.

\subsection{Individual stock-level analysis}

In the Fama-MacBeth regression, it is possible to use several control variables and to take into account individual stock-level information. In the test, I first estimate the explanatory variables for each month, using cross-section regression. I take the mean of the resulting monthly coefficients and then also test it using the NeweyWest corrected t-statistics. The accuracy of the results is ensured by the use of crosssection regression on a monthly basis, which does not require the assumptions necessary for time series analysis.

Both methodologies have their advantages and disadvantages. Examining the issue using only one method can significantly distort the obtained results: hence the need for the relatively complex and comprehensive study described.

\section{Data}

Much of the financial research focuses on US stock exchanges and stock returns. In addition, ESG-based investment is already very common in this market. Therefore, my study focuses on stocks listed on the New York Stock Exchange (NYSE). For this market, the CRSP database is the most commonly used (Fama - French 2018), but due to lack of access to it I used the second most popular and also reliable (Méró et al. 2019; Ince - Porter 2006) Thomson Reuters Datastream database. In this 
case, it is particularly important to carry out appropriate data cleaning, following the study of Ince - Porter (2006). The advantage of the database is the availability of the so-called 'total return index', which is the value adjusted for dividend and change in the number of shares, so their bias can be easily eliminated. In addition, the database includes stocks previously traded but already delisted from the stock exchange, which are also needed to avoid survival bias (Shumway 1997).

For data cleaning, I follow the procedures proposed by Ince - Porter (2006) with some additions. To filter out data errors, I delete monthly (not annualised) returns above 200 per cent, and, based on the turnover data, I also delete data on nontraded stocks (Amihud 2002). In their study, Ince - Porter (2006) suggest that stocks traded at low prices should be deleted, as they can cause biases. For US stock markets, this threshold is most often USD 5, so I omit from the analysis all observations where the stock price does not reach the threshold level. Omitting firms with low market capitalisation is also commonly used to reduce the likelihood that results will be largely driven by the stocks of small firms (Mérö et al. 2019). In the present study, based on market capitalisation, I deleted the 5 per cent smallest observations. I winsorised the variables at the 1 per cent level, not reducing the number of observations, but reducing the effect of outlier values. In order to obtain the most accurate results, I required ESG and ENV scores for at least 500 stocks (for each month separately) over the period under review. After these cleanings and filtering criteria, the database contains 87,344 pieces of data from the New York Stock Exchange for the period from 1 January 2007 to 1 December 2019. As for the robustness test, the shorter period is between 1 January 2013 and 1 December 2019. I discuss this later in more detail.

\section{Results}

\subsection{ESG and ENV in the total market}

First, I examine the profitability of the investment strategy, described in Chapter 2, on the basis of ESG and ENV for the total market. I apply both tercile- and decilebased sorts, assuming that the market is more sensitive to the latter with more detailed breakdown. However, this cannot be justified, as regardless of whether a tercile- or decile-based scale is used, the return for ESG is not significant; moreover, it is slightly negative (Table 1). Robustness is confirmed by the fact that equal or market-value weighting does not have much effect in the present case, and value weighting also does not move the results. 


\section{Table 1}

ESG, tercile- and decile-based sorts (2007-2019, total market)

\begin{tabular}{|c|c|c|c|c|c|c|}
\hline & \multirow[b]{2}{*}{ Quantile } & \multirow[b]{2}{*}{ Mean ESG } & \multicolumn{2}{|c|}{ Equal-weighted portfolio } & \multicolumn{2}{|c|}{ Value-weighted portfolio } \\
\hline & & & Mean return & $\begin{array}{c}\text { Newey- } \\
\text { West t }\end{array}$ & Mean return & $\begin{array}{c}\text { Newey- } \\
\text { West t }\end{array}$ \\
\hline \multirow{7}{*}{ ESG } & 1. & 22.27 & $0.92 \%$ & $(2.30)^{* *}$ & $0.91 \%$ & $(2.29)^{* *}$ \\
\hline & 2. & 41.70 & $0.88 \%$ & $(2.17)^{* *}$ & $0.88 \%$ & $(2.19)^{* *}$ \\
\hline & 3. & 69.27 & $0.91 \%$ & $(2.63)^{* * *}$ & $0.91 \%$ & $(2.66)^{* * *}$ \\
\hline & 3.-1. & - & $-0.01 \%$ & $-(0.09)$ & $0.00 \%$ & $-(0.05)$ \\
\hline & 1. & 15.54 & $0.97 \%$ & $(2.48)^{* *}$ & $0.88 \%$ & $(2.86)^{* * *}$ \\
\hline & 10. & 79.82 & $0.88 \%$ & $(2.87)^{* * *}$ & $0.96 \%$ & $(2.46)^{* *}$ \\
\hline & 10.-1. & - & $-0.09 \%$ & $-(0.75)$ & $-0.08 \%$ & $-(0.69)$ \\
\hline
\end{tabular}

Note: Portfolio 1 contains the stocks with the lowest ESG value, while Portfolio 3 (or 10) contains the stocks with the highest ESG value. *** Significant at 1 per cent, ** at 5 per cent, * at 10 per cent.

The results are similar for ENV. There are no significant returns for either the tercileor the decile-based scale; they show slightly negative returns (Table 2). Similar assumptions can be made as in the previous case, i.e. that the market is more sensitive to outlier values, but this cannot be demonstrated here either. Equal or market weighting also has no effect on the result, which confirms robustness.

\section{Table 2}

ENV, tercile- and decile-based sorts (2007-2019, total market)

\begin{tabular}{|c|c|c|c|c|c|c|}
\hline & \multirow[b]{2}{*}{ Quantile } & \multirow[b]{2}{*}{ Mean ENV } & \multicolumn{2}{|c|}{ Equal-weighted portfolio } & \multicolumn{2}{|c|}{ Value-weighted portfolio } \\
\hline & & & Mean return & $\begin{array}{c}\text { Newey- } \\
\text { West t }\end{array}$ & Mean return & $\begin{array}{l}\text { Newey- } \\
\text { West t }\end{array}$ \\
\hline \multirow{7}{*}{ ENV } & 1. & 9.25 & $0.99 \%$ & $(3.07)^{* * *}$ & $0.99 \%$ & $(3.09)^{* * *}$ \\
\hline & 2. & 37.05 & $1.00 \%$ & $(3.11)^{* * *}$ & $1.00 \%$ & $(3.13)^{* * *}$ \\
\hline & 3. & 72.24 & $0.94 \%$ & $(3.49)^{* * *}$ & $0.93 \%$ & $(3.52)^{* * *}$ \\
\hline & 3.-1. & - & $-0.05 \%$ & $-(0.64)$ & $-0.05 \%$ & $-(0.65)$ \\
\hline & 1. & 3.12 & $0.95 \%$ & $(2.84)^{* * *}$ & $0.87 \%$ & $(3.13)^{* * *}$ \\
\hline & 10. & 84.19 & $0.87 \%$ & $(3.13)^{* * *}$ & $0.96 \%$ & $(2.76)^{* * *}$ \\
\hline & 10.-1. & - & $-0.08 \%$ & $-(0.76)$ & $-0.09 \%$ & $-(0.74)$ \\
\hline
\end{tabular}

Note: Portfolio 1 contains the stocks with the lowest ENV value, while Portfolio 3 (or 10) contains the stocks with the highest ENV value. *** Significant at 1 per cent, ** at 5 per cent, * at 10 per cent. 
The Fama-Macbeth regressions show significant negative coefficients, but their values are much lower than those of the other factors (Table 3). The economic significance of the impact of ESG and ENV is therefore negligible. This is basically consistent with the results of the univariate sort for both variables, where I have obtained non-significant results.

\begin{tabular}{l|c|c}
\hline \multicolumn{3}{l}{ Table 3 } \\
ESG and ENV, Fama-MacBeth regression (2007-2019, total market) \\
\multicolumn{1}{c|}{ Variable } & 1 & 2 \\
\hline ESG & -0.0059 & - \\
\hline ENV & $-(4.45)^{* * *}$ & -0.0037 \\
& - & $-(4.11)^{* * *}$ \\
\hline Beta & & 0.0375 \\
& 0.0859 & $(0.10)$ \\
\hline Size & $(0.18)$ & 0.0821 \\
& 0.1098 & $(4.32)^{* * *}$ \\
\hline Btm & $(4.30)^{* * *}$ & -0.2218 \\
& -0.2412 & $-(6.93)^{* * *}$ \\
\hline Mom & $-(6.61)^{* * *}$ & -0.4613 \\
& -0.8507 & $-(1.03)$ \\
\hline
\end{tabular}

Note: In the regressions, I explained returns by ESG or ENV as well as control variables, which are: market beta (Beta), market capitalisation (Size), book-to-market ratio (Btm) and momentum (Mom). The table shows the time-series mean of the coefficients $(x 100)$ as well as the corresponding Newey-West t-statistics in parentheses. *** Significant at 1 per cent, ** at 5 per cent, * at 10 per cent.

Overall, looking at the total market, there is a weak negative relationship between the indicators examined and the stock returns. The direction of the relationship is unanimously negative, but its significance is highly questionable from both a statistical and an economic point of view. On the basis of this, the higher profits assumed from responsible and sustainable investments do not yet materialise; in fact, minor return losses may occur. Based on the above considerations, looking at the total market, I reject the hypothesis put forward.

\subsection{Detailed industry breakdown}

To obtain a comprehensive picture of the profitability of responsible and sustainable investments, a more detailed analysis than total market analysis is needed. Different industries have a number of characteristics, such as different environmental conditions and features. It is therefore logical to examine the industry breakdown. In this subchapter, I break down the total market into 25 main industries. My assumption is that responsible behaviour matters more within the industry, and that this may be important for direct competitors (actors in the same industry) 
(Kumar et al. 2016). Numerous psychological and behavioural economics studies 4 have found that people tend to make decisions based on context ${ }^{5}$ rather than deal with the given values in themselves. On this basis, my hypothesis is that if I apply the existing investment strategy within industries, I can achieve higher profits. Due to the breakdown of the data, the element number of the sample is reduced, and thus, in this case, I only examine the returns of the tercile-based strategy.

For ESG (Table 4), at all standard significance levels, a significant positive relationship is observed only in the apparel industry, which means a monthly return of 0.62 per cent. The transportation industry also shows some positive returns, but it is not significant even at the 10 per cent level. Of the 25 industries examined, 4 show significant negative returns, namely textiles, tobacco, miscellaneous and automotive. What they all have in common is that none of them are particularly environmentally friendly, and the mean ESG score is relatively low in each sector. Most other sectors show mainly negative but not significant returns. Market-valueweighted returns confirm the robustness of the results.

\begin{tabular}{|c|c|c|c|c|}
\hline \multicolumn{5}{|c|}{$\begin{array}{l}\text { Table } 4 \\
\text { ESG, tercile-based sort (2007-2019, industry breakdown detail) }\end{array}$} \\
\hline \multirow[b]{2}{*}{ Industry } & \multicolumn{2}{|c|}{ Equal-weighted portfolio } & \multicolumn{2}{|c|}{ Value-weighted portfolio } \\
\hline & Mean return & Newey-West t & Mean return & Newey-West t \\
\hline Apparel (16) & $0.62 \%$ & $(2.75)^{* * *}$ & $0.64 \%$ & $(2.92)^{* * *}$ \\
\hline Automotive (19) & $-0.52 \%$ & $-(1.98)^{* *}$ & $-0.52 \%$ & $-(2.04)^{* *}$ \\
\hline Textiles (73) & $-1.70 \%$ & $-(3.25)^{* *}$ & $-1.71 \%$ & $-(3.25)^{* * *}$ \\
\hline Tobacco (76) & $-0.16 \%$ & $-(1.65)^{*}$ & $-0.15 \%$ & $-(1.46)$ \\
\hline Transportation (79) & $0.31 \%$ & $(1.15)$ & $0.30 \%$ & $(1.11)$ \\
\hline Miscellaneous (85) & $-0.17 \%$ & $-(1.69)^{*}$ & $-0.16 \%$ & $-(1.57)$ \\
\hline \multicolumn{5}{|c|}{$\begin{array}{l}\text { Note: The table, based on ESG, shows the tercile-scaled investment strategy return, which I obtain by } \\
\text { subtracting the bottom-tercile return from the return of the portfolio containing the top tercile. Only the } \\
\text { major (significant or near-significant) results have been included in the table. (The full table is available } \\
\text { on request.)*** Significant at } 1 \text { per cent, ** at } 5 \text { per cent, * at } 10 \text { per cent. }\end{array}$} \\
\hline
\end{tabular}

As for ENV (Table 5), a significant positive relationship is also only found in the apparel industry. The monthly return of 0.49 per cent is significant here only at the 10 -per cent significance level. Results for the transportation industry are also similar to those for ESG. There are several industries, namely textiles; tobacco; automotive; electrical; oil, gas and coal; diversified; and food, which have significant negative returns, but in most industries, the obtained results are not significant here either.

\footnotetext{
${ }^{4}$ Several works have been written summarising behavioural studies (e.g. Golovics 2015; Neszveda 2018).

${ }^{5} \mathrm{~A}$ number of economic models have been developed on context dependence and its significance (e.g. Kőszegi - Szeidl 2013; Bordalo et al. 2013; Bakó et al., 2018; Bakó - Neszveda 2020).
} 


\begin{tabular}{|c|c|c|c|c|}
\hline \multirow[b]{2}{*}{ Industry } & \multicolumn{2}{|c|}{ Equal-weighted portfolio } & \multicolumn{2}{|c|}{ Value-weighted portfolio } \\
\hline & Mean return & Newey-West $t$ & Mean return & Newey-West $t$ \\
\hline Apparel (16) & $0.49 \%$ & $(1.81)^{*}$ & $0.50 \%$ & $(1.83)^{*}$ \\
\hline Automotive (19) & $-0.47 \%$ & $-(2.45)^{* *}$ & $-0.50 \%$ & $-(2.67)^{* * *}$ \\
\hline Diversified (31) & $-0.28 \%$ & $-(2.14)^{* *}$ & $-0.31 \%$ & $-(2.35)^{* *}$ \\
\hline Electrical & $-1.44 \%$ & $-(4.90)^{* * *}$ & $-1.40 \%$ & $-(4.20)^{* * *}$ \\
\hline Food (46) & $-0.32 \%$ & $-(1.68)^{*}$ & $-0.33 \%$ & $-(1.70)^{*}$ \\
\hline Oil, Gas and Coal (58) & $-0.41 \%$ & $-(2.21)^{* *}$ & $-0.42 \%$ & $-(2.24)^{* *}$ \\
\hline Textiles (73) & $-0.45 \%$ & $-(2.56)^{* *}$ & $-0.39 \%$ & $-(2.11)^{* *}$ \\
\hline Tobacco (76) & $-0.33 \%$ & $-(1.88)$ & $-0.26 \%$ & $-(1.45)$ \\
\hline Transportation (79) & $0.31 \%$ & $(1.33)$ & $0.30 \%$ & (1.29) \\
\hline \multicolumn{5}{|c|}{$\begin{array}{l}\text { Note: The table, based on ENV, shows the tercile-scaled investment strategy return, which I obtain by } \\
\text { subtracting the bottom-tercile return from the return of the portfolio containing the top tercile. Only the } \\
\text { major (significant or near-significant) results have been included in the table. (The full table is available } \\
\text { on request.) *** Significant at } 1 \text { per cent, ** at } 5 \text { per cent, * at } 10 \text { per cent. }\end{array}$} \\
\hline
\end{tabular}

Overall, we obtain a rather mixed picture, which is in line with the results of Cao et al. (2020). Some industries can be distinguished where responsible and sustainable behaviour may have significance, but even in these, the negative relationship tends to dominate. Negative returns are mainly seen in the industries with lower ESG or ENV ratings. This indicates that investors do not yet necessarily value sustainability (Kumar et al. 2016); in fact, in more-polluting sectors, it may even be a disadvantage. Based on this analysis, I reject my hypothesis that higher profits can be achieved by applying the existing investment strategies within industries.

\subsection{Tests on groups}

The results so far show that the mean ESG or ENV score across industries can affect the evolution of returns. To investigate this further, I divide the 25 industries tested so far into 5 groups (each group includes 5 industries), based on whether the mean industry score is very low, low, medium, high or very high. In this chapter, I present the results of tests on the groups thus formed. My hypothesis is that if I apply the existing investment strategy within groups, I can achieve higher profits.

Contrary to expectations, the results (Table 6) show that ESG has no impact on the returns. The returns of none of the portfolios are significant. The results are slightly better for the decile-based scale; the portfolio return is close to significant in the very high ESG group, but still not acceptable even at the 10 per cent level. Value weighting also confirms the results; the differences are negligible. 


\begin{tabular}{|c|c|c|c|c|c|c|}
\hline \multicolumn{7}{|l|}{$\begin{array}{l}\text { Table } 6 \\
\text { ESG, terc }\end{array}$} \\
\hline & \multirow[b]{2}{*}{ Quantile } & \multirow[b]{2}{*}{ Mean ESG } & \multicolumn{2}{|c|}{ Equal-weighted portfolio } & \multicolumn{2}{|c|}{ Value-weighted portfolio } \\
\hline & & & Mean return & $\begin{array}{l}\text { Newey- } \\
\text { West t }\end{array}$ & Mean return & $\begin{array}{l}\text { Newey- } \\
\text { West t }\end{array}$ \\
\hline \multirow{4}{*}{$\begin{array}{l}\text { Very low }(28,55,58 \text {, } \\
73,49)\end{array}$} & 1. & 17.93 & $0.83 \%$ & $(1.97)^{* *}$ & $0.83 \%$ & $(1.96)^{* *}$ \\
\hline & 2. & 31.66 & $0.80 \%$ & $(2.08)^{* *}$ & $0.80 \%$ & $(2.09)^{* *}$ \\
\hline & 3. & 59.21 & $0.76 \%$ & $(1.80)^{*}$ & $0.76 \%$ & $(1.84)^{*}$ \\
\hline & 3.-1. & - & $-0.07 \%$ & $-(0.82)$ & $-0.07 \%$ & $-(0.73)$ \\
\hline \multirow[t]{4}{*}{ Low $(85,43,37,13,79)$} & 1. & 21.60 & $0.91 \%$ & $(2.27)^{* *}$ & $0.91 \%$ & $(2.26)^{* *}$ \\
\hline & 2. & 38.46 & $0.89 \%$ & $(2.13)^{* *}$ & $0.89 \%$ & $(2.14)^{* *}$ \\
\hline & 3. & 64.26 & $0.85 \%$ & $(2.02)^{* *}$ & $0.85 \%$ & $(2.04)^{* *}$ \\
\hline & 3.-1. & - & $-0.06 \%$ & $-(0.76)$ & $-0.06 \%$ & $-(0.72)$ \\
\hline \multirow{4}{*}{$\begin{array}{l}\text { Medium }(19,67,52,40 \text {, } \\
61)\end{array}$} & 1. & 23.56 & $1.03 \%$ & $(2.33)^{* *}$ & $1.03 \%$ & $(2.34)^{* *}$ \\
\hline & 2. & 44.51 & $0.82 \%$ & $(1.72)^{*}$ & $0.82 \%$ & $(1.73)^{*}$ \\
\hline & 3. & 70.43 & $0.92 \%$ & $(2.53)^{* *}$ & $0.93 \%$ & $(2.58)^{* * *}$ \\
\hline & 3.-1. & - & $-0.10 \%$ & $-(0.81)$ & $-0.10 \%$ & $-(0.78)$ \\
\hline \multirow{4}{*}{$\begin{array}{l}\text { High }(64,25,82,70 \text {, } \\
16)\end{array}$} & 1. & 26.21 & $0.93 \%$ & $(2.35)^{* *}$ & $0.92 \%$ & $(2.35)^{* *}$ \\
\hline & 2. & 48.26 & $0.92 \%$ & $(2.42)^{* *}$ & $0.92 \%$ & $(2.43)^{* *}$ \\
\hline & 3. & 71.75 & $0.90 \%$ & $(2.94)^{* * *}$ & $0.90 \%$ & $(2.97)^{* * *}$ \\
\hline & 3.-1. & - & $-0.03 \%$ & $-(0.22)$ & $-0.02 \%$ & $-(0.18)$ \\
\hline \multirow{4}{*}{$\begin{array}{l}\text { Very high }(34,22,31 \text {, } \\
46,76)\end{array}$} & 1. & 29.54 & $1.06 \%$ & $(3.06)^{* * *}$ & $1.06 \%$ & $(3.05)^{* * *}$ \\
\hline & 2. & 56.18 & $1.05 \%$ & $(3.08)^{* * *}$ & $1.05 \%$ & $(3.09)^{* * *}$ \\
\hline & 3. & 79.14 & $0.96 \%$ & $(3.72)^{* * *}$ & $0.96 \%$ & $(3.69)^{* * *}$ \\
\hline & 3. -1 . & - & $-0.10 \%$ & $-(0.63)$ & $-0.09 \%$ & $-(0.60)$ \\
\hline Very low & 10.-1. & - & $-0.07 \%$ & $-(0.54)$ & $-0.08 \%$ & $-(0.64)$ \\
\hline Low & 10.-1. & - & $-0.13 \%$ & $-(1.05)$ & $-0.11 \%$ & $-(0.93)$ \\
\hline Medium & 10.-1. & - & $-0.06 \%$ & $-(0.32)$ & $-0.03 \%$ & $-(0.14)$ \\
\hline High & 10.-1. & - & $-0.08 \%$ & $-(0.45)$ & $-0.09 \%$ & $-(0.46)$ \\
\hline Very high & 10.-1. & - & $-0.28 \%$ & $-(1.46)$ & $-0.26 \%$ & $-(1.34)$ \\
\hline
\end{tabular}

The results are similar for ENV (Table 7), with the difference that here, for the tercile-based scale, the very low group shows an almost significant result. The results obtained cannot be considered significant at all. The preliminary assumption that the mean ESG or ENV score of an industry may play a decisive role is not confirmed. 


\begin{tabular}{|c|c|c|c|c|c|c|}
\hline \multicolumn{7}{|l|}{ Table 7} \\
\hline & \multirow[b]{2}{*}{ Quantile } & \multirow[b]{2}{*}{ Mean ENV } & \multicolumn{2}{|c|}{ Equal-weighted portfolio } & \multicolumn{2}{|c|}{ Value-weighted portfolio } \\
\hline & & & Mean return & $\begin{array}{l}\text { Newey- } \\
\text { West t }\end{array}$ & Mean return & $\begin{array}{c}\text { Newey- } \\
\text { West t }\end{array}$ \\
\hline \multirow{4}{*}{$\begin{array}{l}\text { Very low }(28,55,85 \text {, } \\
73,43)\end{array}$} & 1. & 6.81 & $0.99 \%$ & $(3.00)^{* * *}$ & $0.98 \%$ & $(2.98) * * *$ \\
\hline & 2. & 27.58 & $1.03 \%$ & $(3.02)^{* * *}$ & $1.03 \%$ & $(3.03) * * *$ \\
\hline & 3. & 64.84 & $0.85 \%$ & $(2.40)^{* *}$ & $0.86 \%$ & $(2.42)^{* *}$ \\
\hline & 3.-1. & - & $-0.13 \%$ & $-(1.47)$ & $-0.13 \%$ & $-(1.37)$ \\
\hline \multirow[t]{4}{*}{$\operatorname{Low}(49,58,70,13,19)$} & 1. & 7.10 & $0.94 \%$ & $(2.14)^{* *}$ & $0.94 \%$ & $(2.16)^{* *}$ \\
\hline & 2. & 32.48 & $0.85 \%$ & $(2.41)^{* *}$ & $0.85 \%$ & $(2.42)^{* *}$ \\
\hline & 3. & 74.34 & $0.95 \%$ & $(3.09)^{* * *}$ & $0.94 \%$ & $(3.13)^{* * *}$ \\
\hline & 3.-1. & - & $-0.13 \%$ & $-(1.15)$ & $-0.13 \%$ & $-(1.16)$ \\
\hline \multirow{4}{*}{$\begin{array}{l}\text { Medium }(40,64,52 \text {, } \\
67,79)\end{array}$} & 1. & 10.96 & $0.99 \%$ & $(2.67)^{* * *}$ & $0.99 \%$ & $(2.68)^{* * *}$ \\
\hline & 2. & 39.63 & $0.95 \%$ & $(2.71)^{* * *}$ & $0.95 \%$ & $(2.74)^{* * *}$ \\
\hline & 3. & 71.95 & $1.01 \%$ & $(3.31)^{* * *}$ & $1.01 \%$ & $(3.37)^{* * *}$ \\
\hline & 3.-1. & - & $0.02 \%$ & $(0.14)$ & $0.02 \%$ & $(0.15)$ \\
\hline \multirow[t]{4}{*}{ High $(37,16,34,82,25)$} & 1. & 14.99 & $1.07 \%$ & $(3.60)^{* * *}$ & $1.07 \%$ & $(3.60)^{* * *}$ \\
\hline & 2. & 45.36 & $1.06 \%$ & $(4.05)^{* * *}$ & $1.06 \%$ & $(4.07)^{* * *}$ \\
\hline & 3. & 73.79 & $0.99 \%$ & $(4.36)^{* * *}$ & $0.98 \%$ & $(4.37)^{* * *}$ \\
\hline & 3.-1. & - & $-0.10 \%$ & $-(0.82)$ & $-0.10 \%$ & $-(0.85)$ \\
\hline \multirow{4}{*}{$\begin{array}{l}\text { Very high }(31,22,61 \text {, } \\
46,76)\end{array}$} & 1. & 19.23 & $0.97 \%$ & $(2.54)^{* *}$ & $0.97 \%$ & $(2.56)^{* *}$ \\
\hline & 2. & 50.80 & $1.02 \%$ & $(3.51)^{* * *}$ & $1.02 \%$ & $(3.55)^{* * *}$ \\
\hline & 3. & 77.46 & $0.99 \%$ & $(3.84)^{* * *}$ & $0.98 \%$ & $(3.78)^{* * *}$ \\
\hline & 3.-1. & - & $0.05 \%$ & $(0.35)$ & $0.04 \%$ & $(0.27)$ \\
\hline Very low & 10.-1. & - & $0.03 \%$ & $(0.17)$ & $0.01 \%$ & $(0.04)$ \\
\hline Low & 10.-1. & - & $-0.18 \%$ & $-(1.07)$ & $-0.25 \%$ & $-(1.29)$ \\
\hline Medium & 10.-1. & - & $-0.12 \%$ & $-(0.70)$ & $-0.13 \%$ & $-(0.64)$ \\
\hline High & 10.-1. & - & $-0.05 \%$ & $-(0.32)$ & $0.00 \%$ & $-(0.04)$ \\
\hline Very high & $10 .-1$. & - & $0.06 \%$ & $(0.27)$ & $0.13 \%$ & $(0.58)$ \\
\hline
\end{tabular}

Note: Portfolio 1 contains the stocks with the lowest ENV value, while Portfolio 3 (or 10) contains the stocks with the highest ENV value, within the group. *** Significant at 1 per cent, ** at 5 per cent, * at 10 per cent.

When using Fama-Macbeth regression for a total market analysis, I obtained statistically significant results, so this may also be interesting in the case of group breakdown. Using ESG as an explanatory variable (Table 8), we can see that the relationship is significantly negative for all but the medium group. As with the total market, the coefficient of ESG is lower than that of the control factors; its economic 
significance is negligible. What can be observed is that the coefficient is higher for the extreme groups.

Using ENV as an explanatory variable (Table 9), we can see a significant negative coefficient in all cases, again with the exception of the medium group. It can also be observed that the effect is stronger for the extreme groups. It is strongest in the very high ENV group, but even there, its economic significance is negligible.

\begin{tabular}{|c|c|c|c|c|c|}
\hline \multicolumn{6}{|c|}{$\begin{array}{l}\text { Table } 8 \\
\text { ESG, Fama-MacBeth regression (2007-2019, industry grouping) }\end{array}$} \\
\hline Variable & 1 & 2 & 3 & 4 & 5 \\
\hline Very low & $\begin{array}{l}-0.0060 \\
-(2.53)^{* *}\end{array}$ & - & - & - & - \\
\hline Low & - & $\begin{array}{l}-0.0058 \\
-(3.20)^{* * *}\end{array}$ & - & - & - \\
\hline Medium & - & - & $\begin{array}{l}-0.0030 \\
-(0.12)\end{array}$ & - & - \\
\hline High & - & - & - & $\begin{array}{c}-0.0064 \\
-(3.22)^{* * *}\end{array}$ & - \\
\hline Very high & - & - & - & - & $\begin{array}{r}-0.0088 \\
-(3.07)^{* * *}\end{array}$ \\
\hline Beta & $\begin{array}{c}0.34 \\
(0.66)\end{array}$ & $\begin{array}{c}0.17 \\
(0.32)\end{array}$ & $\begin{array}{c}0.34 \\
(0.64)\end{array}$ & $\begin{array}{l}-0.21 \\
-(0.43)\end{array}$ & $\begin{array}{c}0.19 \\
(0.44)\end{array}$ \\
\hline Size & $\begin{array}{c}0.11 \\
(2.20)^{* *}\end{array}$ & $\begin{array}{c}0.11 \\
(4.08)^{* * *}\end{array}$ & $\begin{array}{c}0.05 \\
(1.41)\end{array}$ & $\begin{array}{c}0.11 \\
(2.15)^{* *}\end{array}$ & $\begin{array}{c}0.06 \\
(1.80)^{*}\end{array}$ \\
\hline Btm & $\begin{array}{c}-0.28 \\
-(5.29) * * *\end{array}$ & $\begin{array}{c}-0.20 \\
-(3.72)^{* * *}\end{array}$ & $\begin{array}{c}-0.39 \\
-(5.51)^{* * *}\end{array}$ & $\begin{array}{c}-0.27 \\
-(7.47)^{* * *}\end{array}$ & $\begin{array}{c}-0.23 \\
-(3.69)^{* * *}\end{array}$ \\
\hline Mom & $\begin{array}{c}0.05 \\
(0.10)\end{array}$ & $\begin{array}{l}-0.79 \\
-(1.41)\end{array}$ & $\begin{array}{l}-0.63 \\
-(1.13)\end{array}$ & $\begin{array}{c}-1.71 \\
-(2.63)^{* * *}\end{array}$ & $\begin{array}{c}-1.38 \\
-(2.30)^{* *}\end{array}$ \\
\hline
\end{tabular}

Note: In the regressions, I have explained returns by ESG as well as control variables, which are: market beta (Beta), market capitalisation (Size), book-to-market ratio (Btm) and momentum (Mom). The table shows the time-series mean of the coefficients $(x 100)$ as well as the corresponding Newey-West t-statistics in parentheses. *** Significant at 1 per cent, ** at 5 per cent, * at 10 per cent. 


\begin{tabular}{|c|c|c|c|c|c|}
\hline \multicolumn{6}{|c|}{$\begin{array}{l}\text { Table } 9 \\
\text { ENV, Fama-MacBeth regression (2007-2019, industry grouping) }\end{array}$} \\
\hline Variable & 1 & 2 & 3 & 4 & 5 \\
\hline Very low & $\begin{array}{l}-0.0027 \\
-(1.65)^{*}\end{array}$ & - & - & - & - \\
\hline Low & - & $\begin{array}{l}-0.0039 \\
-(1.66)^{*}\end{array}$ & - & - & - \\
\hline Medium & - & - & $\begin{array}{l}-0.0018 \\
-(0.95)\end{array}$ & - & - \\
\hline High & - & - & - & $\begin{array}{l}-0.0020 \\
-(1.81)^{*}\end{array}$ & - \\
\hline Very high & - & - & - & - & $\begin{array}{l}-0.0045 \\
-(2.35)^{* *}\end{array}$ \\
\hline Beta & $\begin{array}{l}-0.05 \\
-(0.12)\end{array}$ & $\begin{array}{l}-0.08 \\
-(0.18)\end{array}$ & $\begin{array}{c}0.16 \\
(0.45)\end{array}$ & $\begin{array}{c}0.00 \\
(0.01)\end{array}$ & $\begin{array}{c}0.23 \\
(0.61)\end{array}$ \\
\hline Size & $\begin{array}{c}0.09 \\
(2.58)^{* * *}\end{array}$ & $\begin{array}{c}0.08 \\
(2.14)^{* *}\end{array}$ & $\begin{array}{c}0.11 \\
(2.30)^{* *}\end{array}$ & $\begin{array}{c}0.01 \\
(0.16)\end{array}$ & $\begin{array}{c}0.04 \\
(0.90)\end{array}$ \\
\hline Btm & $\begin{array}{c}-0.23 \\
-(3.61)^{* * *}\end{array}$ & $\begin{array}{c}-0.30 \\
-(4.54)^{* * *}\end{array}$ & $\begin{array}{c}-0.33 \\
-(4.07)^{* * *}\end{array}$ & $\begin{array}{l}-0.19 \\
-(4.47)\end{array}$ & $\begin{array}{c}-0.13 \\
-(1.96)^{* *}\end{array}$ \\
\hline Mom & $\begin{array}{l}-0.30 \\
-(0.47)\end{array}$ & $\begin{array}{c}0.21 \\
(0.32)\end{array}$ & $\begin{array}{l}-0.82 \\
-(1.34)\end{array}$ & $\begin{array}{l}-0.60 \\
-(1.18)\end{array}$ & $\begin{array}{c}-0.78 \\
-(1.14)\end{array}$ \\
\hline
\end{tabular}

Note: In the regressions, I have explained returns by ENV as well as control variables, which are: market beta (Beta), market capitalisation (Size), book-to-market ratio (Btm) and momentum (Mom). The table shows the time-series mean of the coefficients $(x 100)$ as well as the corresponding Newey-West t-statistics in parentheses. *** Significant at 1 per cent, ** at 5 per cent, * at 10 per cent.

Overall, for groupings based on the mean ESG and ENV scores in the industries, the univariate-sort-based portfolio creation shows no significant returns, and the FamaMacbeth regressions show a negative relationship, but the economic significance is negligible. Although, to the best of my knowledge, the same analysis has not yet been performed in previous studies, I have obtained results consistent with similar studies by Auer - Schuhmacher (2016); according to which a high or low ranking does not result in a significant difference in returns. Furthermore, in some cases, a negative relationship can be seen. I, therefore, reject the hypothesis proposed at the beginning of the chapter.

\subsection{Relative ESG and relative ENV, tests on groups}

The previous tests suggest, in part, that if the market does not generally value ESG or ENV, it may still be sensitive to extreme values. In this subchapter, I examine this issue. To measure this, I use relative ESG and relative ENV, which I calculate by subtracting the industry mean from the given score. This shows the signed distance 
from the industry mean. My hypothesis is that stocks with higher relative scores provide higher returns. The results so far point in the direction that responsible and sustainable investments have basically no impact on returns. I, therefore, present the relative tests directly in a group breakdown, ${ }^{6}$ using as much additional information as possible from the scores. The total industry breakdown in this case can no longer be interpreted separately; it would give exactly the same result as a test of simple scores.

For the tercile scale of relative-ESG-based strategy (see Table 10), no significant returns are seen anywhere. For the decile-based scale, I obtain slightly higher returns, and the very high group shows a significant monthly return of -0.34 per cent at the 10 per cent significance level. The results are the same for both equal and value weighting, and show that in industries with inherently very high ESG scores, there is a negative relationship between ESG and returns, i.e. it is not worth investing in stocks with high ESG.

The results for ENV are somewhat different (Table 11), with a significant monthly return of -0.18 per cent for the tercile-based scale in the very low category (again only at the 10 per cent level). The decile-based scale amplifies this to -0.34 per cent, but this is more sensitive to market-value weighting. The result shows that in industries with inherently very low ENV scores, the relationship between ENV and returns is negative. Therefore, it is also not worth investing in stocks with a higher ENV in this group. However, it is important to note that the results are not robust for any of the indicators examined. Significant returns can only be seen at a high significance level in some places; furthermore, I perform a relatively large number of tests, so this can even be a mere random effect.

\footnotetext{
${ }^{6} \mathrm{I}$ also performed the test on the total market, where it had no particular impact on the results; accordingly, for the sake of the transparency of the tables, they are not included in the study, but are available on request.
} 
Table 10

Relative ESG, tercile- and decile-based sorts (2007-2019, industry grouping)

\begin{tabular}{|c|c|c|c|c|c|}
\hline & \multirow{2}{*}{ Quantile } & \multicolumn{2}{|c|}{ Equal-weighted portfolio } & \multicolumn{2}{|c|}{ Value-weighted portfolio } \\
\hline & & Mean return & Newey-West $t$ & Mean return & Newey-West t \\
\hline \multirow{4}{*}{$\begin{array}{l}\text { Very low }(28,55,58 \text {, } \\
73,49)\end{array}$} & 1. & $0.91 \%$ & $(2.18)^{* *}$ & $0.91 \%$ & $(2.17)^{* *}$ \\
\hline & 2. & $0.90 \%$ & $(2.32)^{* *}$ & $0.90 \%$ & $(2.34)^{* *}$ \\
\hline & 3. & $0.81 \%$ & $(1.93)^{*}$ & $0.81 \%$ & $(1.97)^{* *}$ \\
\hline & 3.-1. & $-0.10 \%$ & $-(1.08)$ & $-0.10 \%$ & $-(0.99)$ \\
\hline \multirow[t]{4}{*}{ Low $(85,43,37,13,79)$} & 1. & $1.00 \%$ & $(2.50) * *$ & $1.00 \%$ & $(2.49)^{* *}$ \\
\hline & 2. & $0.98 \%$ & $(2.34)^{* *}$ & $0.98 \%$ & $(2.35)^{* *}$ \\
\hline & 3. & $0.93 \%$ & $(2.20)^{* *}$ & $0.93 \%$ & $(2.21)^{* *}$ \\
\hline & 3. -1 . & $-0.07 \%$ & $-(0.88)$ & $-0.07 \%$ & $-(0.84)$ \\
\hline \multirow{4}{*}{$\begin{array}{l}\text { Medium }(19,67,52,40 \text {, } \\
61)\end{array}$} & 1. & $1.13 \%$ & $(2.54)^{* *}$ & $1.13 \%$ & $(2.55)^{* *}$ \\
\hline & 2. & $0.91 \%$ & $(1.91)^{*}$ & $0.91 \%$ & $(1.93)^{*}$ \\
\hline & 3. & $1.01 \%$ & $(2.75)^{* * *}$ & $1.01 \%$ & $(2.81)^{* * *}$ \\
\hline & 3. -1 . & $-0.12 \%$ & $-(0.90)$ & $-0.11 \%$ & $-(0.87)$ \\
\hline \multirow{4}{*}{$\begin{array}{l}\text { High }(64,25,82,70 \text {, } \\
\text { 16) }\end{array}$} & 1. & $1.02 \%$ & $(2.61)^{* * *}$ & $1.02 \%$ & $(2.62)^{* * *}$ \\
\hline & 2. & $1.01 \%$ & $(2.65)^{* * *}$ & $1.01 \%$ & $(2.66)^{* * *}$ \\
\hline & 3. & $0.99 \%$ & $(3.27) * * *$ & $1.00 \%$ & $(3.31)^{* * *}$ \\
\hline & 3. -1 . & $-0.03 \%$ & $-(0.20)$ & $-0.02 \%$ & $-(0.17)$ \\
\hline \multirow{4}{*}{$\begin{array}{l}\text { Very high }(34,22,31 \text {, } \\
46,76)\end{array}$} & 1. & $1.17 \%$ & $(3.38)^{* * *}$ & $1.16 \%$ & $(3.36)^{* * *}$ \\
\hline & 2. & $1.13 \%$ & $(3.33)^{* * *}$ & $1.13 \%$ & $(3.34)^{* * *}$ \\
\hline & 3. & $1.08 \%$ & $(4.25)^{* * *}$ & $1.08 \%$ & $(4.20)^{* * *}$ \\
\hline & 3. -1 . & $-0.09 \%$ & $-(0.55)$ & $-0.08 \%$ & $-(0.53)$ \\
\hline Very low & 10.-1. & $-0.05 \%$ & $-(0.28)$ & $-0.12 \%$ & $-(0.77)$ \\
\hline Low & 10.-1. & $-0.15 \%$ & $-(1.13)$ & $-0.17 \%$ & $-(1.22)$ \\
\hline Medium & 10.-1. & $-0.12 \%$ & $-(0.56)$ & $-0.14 \%$ & $-(0.63)$ \\
\hline High & 10.-1. & $-0.10 \%$ & $-(0.55)$ & $-0.09 \%$ & $-(0.50)$ \\
\hline Very high & 10.-1. & $-0.34 \%$ & $-(1.80)^{*}$ & $-0.36 \%$ & $-(1.78)^{*}$ \\
\hline
\end{tabular}

Note: Portfolio 1 contains the stocks with the lowest relative ESG value, while Portfolio 3 (or 10) contains the stocks with the highest relative ESG value, within the group. *** Significant at 1 per cent, ** at 5 per cent, * at 10 per cent. 
Table 11

Relative ENV, tercile- and decile-based sorts (2007-2019, industry grouping)

\begin{tabular}{|c|c|c|c|c|c|}
\hline & \multirow{2}{*}{ Quantile } & \multicolumn{2}{|c|}{ Equal-weighted portfolio } & \multicolumn{2}{|c|}{ Value-weighted portfolio } \\
\hline & & Mean return & Newey-West t & Mean return & Newey-West $t$ \\
\hline \multirow{4}{*}{$\begin{array}{l}\text { Very low }(28,55,85 \text {, } \\
73,43)\end{array}$} & 1. & $0.99 \%$ & $(2.98)^{* * *}$ & $0.99 \%$ & $(2.97)^{* * *}$ \\
\hline & 2. & $1.05 \%$ & $(3.06)^{* * *}$ & $1.04 \%$ & $(3.07)^{* * *}$ \\
\hline & 3. & $0.81 \%$ & $(2.28)^{* *}$ & $0.81 \%$ & $(2.31)^{* *}$ \\
\hline & 3.-1. & $-0.18 \%$ & $-(1.79)^{*}$ & $-0.18 \%$ & $-(1.70)^{*}$ \\
\hline \multirow[t]{4}{*}{ Low $(49,58,70,13,19)$} & 1. & $1.04 \%$ & $(2.82)^{* * *}$ & $1.04 \%$ & $(2.84)^{* * *}$ \\
\hline & 2. & $0.93 \%$ & $(2.67)^{* * *}$ & $0.93 \%$ & $(2.68)^{* * *}$ \\
\hline & 3. & $0.93 \%$ & $(3.21)^{* * *}$ & $0.92 \%$ & $(3.25)^{* * *}$ \\
\hline & 3.-1. & $-0.11 \%$ & $-(0.75)$ & $-0.12 \%$ & $-(0.78)$ \\
\hline \multirow{4}{*}{$\begin{array}{l}\text { Medium }(40,64,52 \text {, } \\
67,79)\end{array}$} & 1. & $0.97 \%$ & $(2.59)^{* * *}$ & $0.97 \%$ & $(2.60)^{* * *}$ \\
\hline & 2. & $0.94 \%$ & $(2.69)^{* * *}$ & $0.94 \%$ & $(2.72)^{* * *}$ \\
\hline & 3. & $1.02 \%$ & $(3.35)^{* * *}$ & $1.02 \%$ & $(3.41)^{* * *}$ \\
\hline & 3.-1. & $0.05 \%$ & $(0.45)$ & $0.05 \%$ & $(0.46)$ \\
\hline \multirow[t]{4}{*}{$\operatorname{High}(37,16,34,82,25)$} & 1. & $0.99 \%$ & $(3.54)^{* * *}$ & $0.99 \%$ & $(3.54)^{* * *}$ \\
\hline & 2. & $1.11 \%$ & $(4.36)^{* * *}$ & $1.10 \%$ & $(4.38)^{* * *}$ \\
\hline & 3. & $0.94 \%$ & $(4.15)^{* * *}$ & $0.93 \%$ & $(4.16)^{* * *}$ \\
\hline & 3.-1. & $-0.05 \%$ & $-(0.49)$ & $-0.06 \%$ & $-(0.55)$ \\
\hline \multirow{4}{*}{$\begin{array}{l}\text { Very high }(31,22,61 \text {, } \\
46,76)\end{array}$} & 1. & $0.96 \%$ & $(2.53)^{* *}$ & $0.97 \%$ & $(2.56)^{* *}$ \\
\hline & 2. & $1.02 \%$ & $(3.56)^{* * *}$ & $1.02 \%$ & $(3.62)^{* * *}$ \\
\hline & 3. & $0.99 \%$ & $(3.76)^{* * *}$ & $0.98 \%$ & $(3.70)^{* * *}$ \\
\hline & 3.-1. & $0.05 \%$ & $(0.37)$ & $0.04 \%$ & (0.29) \\
\hline Very low & 10.-1. & $-0.34 \%$ & $-(1.93)^{*}$ & $-0.25 \%$ & $-(1.56)$ \\
\hline Low & 10.-1. & $-0.10 \%$ & $-(0.60)$ & $0.04 \%$ & $(0.22)$ \\
\hline Medium & 10.-1. & $-0.11 \%$ & $-(0.49)$ & $-0.07 \%$ & $-(0.41)$ \\
\hline High & 10.-1. & $0.10 \%$ & $(0.51)$ & $-0.08 \%$ & $-(0.54)$ \\
\hline Very high & 10.-1. & $-0.31 \%$ & $-(1.27)$ & $-0.09 \%$ & $-(0.40)$ \\
\hline
\end{tabular}

Note: Portfolio 1 contains the stocks with the lowest relative ENV value, while Portfolio 3 (or 10) contains the stocks with the highest relative ENV value, within the group. *** Significant at 1 per cent, ** at 5 per cent, * at 10 per cent. 
The use of relative scores does not substantially change the results of the FamaMacbeth regressions (see Tables 12 and 13). With the exception of the medium group, there is a significant negative relationship in all cases, but their economic significance remains negligible.

\section{Table 12 \\ Relative ESG, Fama-MacBeth regression (2007-2019, industry grouping)}

\begin{tabular}{|c|c|c|c|c|c|}
\hline Variable & 1 & 2 & 3 & 4 & 5 \\
\hline Very low & $\begin{array}{c}-0.0066 \\
-(2.78)^{* * *}\end{array}$ & - & - & - & - \\
\hline Low & - & $\begin{array}{c}-0.0063 \\
-(3.52)^{* * *}\end{array}$ & - & - & - \\
\hline Medium & - & - & $\begin{array}{l}-0.0033 \\
-(0.13) \\
\end{array}$ & - & - \\
\hline High & - & - & - & $\begin{array}{c}-0.0070 \\
-(3.54)^{* * *}\end{array}$ & - \\
\hline Very high & - & - & - & - & $\begin{array}{c}-0.0096 \\
-(3.38)^{* * *}\end{array}$ \\
\hline Beta & $\begin{array}{c}0.37 \\
(0.73)\end{array}$ & $\begin{array}{c}0.18 \\
(0.35)\end{array}$ & $\begin{array}{c}0.37 \\
(0.70)\end{array}$ & $\begin{array}{c}-0.23 \\
-(0.47)\end{array}$ & $\begin{array}{c}0.20 \\
(0.48)\end{array}$ \\
\hline Size & $\begin{array}{c}0.12 \\
(2.42)^{* *}\end{array}$ & $\begin{array}{c}0.12 \\
(4.49)^{* * *}\end{array}$ & $\begin{array}{r}0.06 \\
(1.55) \\
\end{array}$ & $\begin{array}{c}0.12 \\
(2.37)^{* *}\end{array}$ & $\begin{array}{c}0.07 \\
(1.98)^{* *}\end{array}$ \\
\hline Btm & $\begin{array}{c}-0.30 \\
-(5.82)^{* * *}\end{array}$ & $\begin{array}{c}-0.22 \\
-(4.09)^{* * *}\end{array}$ & $\begin{array}{c}-0.43 \\
-(6.06)^{* * *}\end{array}$ & $\begin{array}{c}-0.29 \\
-(8.22)^{* * *}\end{array}$ & $\begin{array}{c}-0.26 \\
-(4.06)^{* * *}\end{array}$ \\
\hline Mom & $\begin{array}{c}0.05 \\
(0.11)\end{array}$ & $\begin{array}{l}-0.87 \\
-(1.55)\end{array}$ & $\begin{array}{l}-0.70 \\
-(1.24)\end{array}$ & $\begin{array}{c}-1.88 \\
-(2.89)^{* * *}\end{array}$ & $\begin{array}{c}-1.52 \\
-(2.53)^{* *}\end{array}$ \\
\hline
\end{tabular}

Note: In the regressions, I explained returns by relative ESG as well as control variables, which are: market beta (Beta), market capitalisation (Size), book-to-market ratio (Btm) and momentum (Mom). The table shows the time-series mean of the coefficients $(\times 100)$ as well as the corresponding Newey-West t-statistics in parentheses. *** Significant at 1 per cent, ** at 5 per cent, * at 10 per cent. 


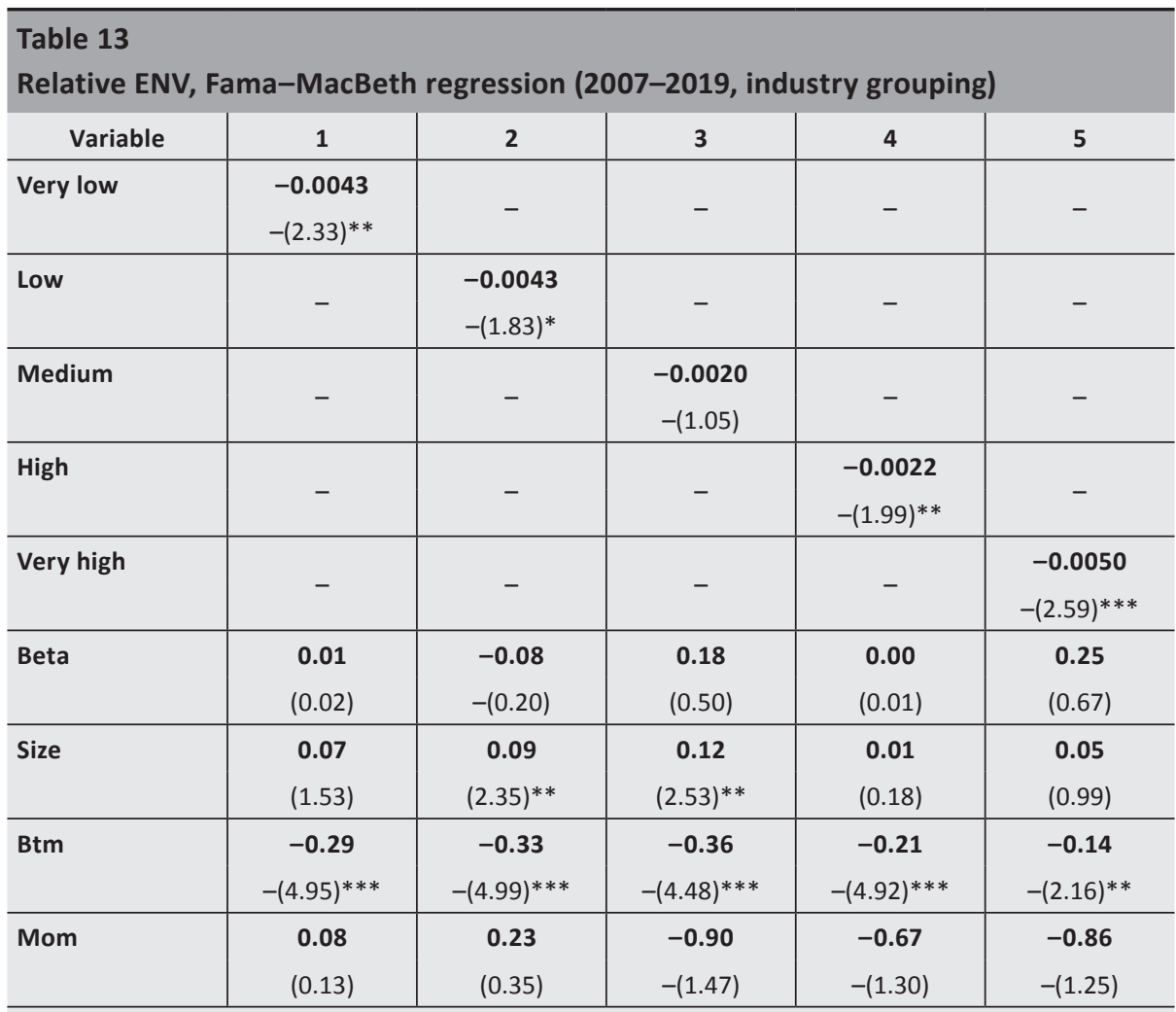

Note: In the regressions, I explained returns by relative ENV as well as control variables, which are: market beta (Beta), market capitalisation (Size), book-to-market ratio (Btm) and momentum (Mom). The table shows the time-series mean of the coefficients $(\times 100)$ as well as the corresponding Newey-West t-statistics in parentheses. *** Significant at 1 per cent, ** at 5 per cent, * at 10 per cent.

Overall, the results obtained for the relative scores also do not differ from the previous. For groupings based on the industry mean, in the context of relative-ESG test, during the univariate-sort-based portfolio creation, only the very high group had significant returns. While for the relative ENV, it was the very low group that had such returns. However, most of the returns are not significant, and the few significant ones may be the result of coincidence. The Fama-Macbeth regressions show a weak negative relationship with a negligible economic impact. Based on these results, I reject the hypothesis that stocks with higher relative scores provide higher returns. 


\subsection{Robustness, temporal decomposition}

Since, according to Halbritter - Dorfleitner (2015), scores can be sensitive to the time horizon, in this chapter, I intend to support the robustness of the results by breaking up the time series studied so far and performing the main parts of the previous tests in a nearer and shorter time horizon. Having become more and more widespread, ESG can have an increasing impact. Therefore, I halved the period covered so far and then focus only on the second half of it (2013-2019), thus excluding the impact of the 2008 crisis, which may also have a major influence on the results.

The tests performed for the shorter time horizon show no substantial difference between ESG and ENV, just as no major difference was observed so far. Thus, for transparency reasons, I only publish the tables for ESG. ${ }^{7}$ In the case of the sort, the main results are not changed by the period breakdown when we examine the total market. Although there is a shift towards positive returns, this cannot be considered significant in either case (Table 14). Here, too, value weighting does not greatly affect the results.

\section{Table 14}

ESG, tercile- and decile-based sorts (2013-2019, total market)

\begin{tabular}{|c|c|c|c|c|c|c|}
\hline & \multirow[b]{2}{*}{ Quantile } & \multirow[b]{2}{*}{ Mean ESG } & \multicolumn{2}{|c|}{ Equal-weighted portfolio } & \multicolumn{2}{|c|}{ Value-weighted portfolio } \\
\hline & & & Mean return & $\begin{array}{l}\text { Newey- } \\
\text { West t }\end{array}$ & Mean return & $\begin{array}{c}\text { Newey- } \\
\text { West t }\end{array}$ \\
\hline \multirow{7}{*}{ ESG } & 1. & 22.45 & $0.89 \%$ & $(2.83)^{* * *}$ & $0.89 \%$ & $(2.84)^{* * *}$ \\
\hline & 2. & 41.42 & $0.92 \%$ & $(3.04)^{* * *}$ & $0.93 \%$ & $(3.05)^{* * *}$ \\
\hline & 3. & 68.81 & $1.00 \%$ & $(3.64)^{* * *}$ & $1.00 \%$ & $(3.69) * * *$ \\
\hline & 3.-1. & - & $0.11 \%$ & $(1.36)$ & $0.11 \%$ & $(1.32)$ \\
\hline & 1. & 15.96 & $0.85 \%$ & $(2.59)^{* * *}$ & $0.86 \%$ & $(2.64)^{* * *}$ \\
\hline & 10. & 79.70 & $0.96 \%$ & $(3.60)^{* * *}$ & $0.96 \%$ & $(3.60)^{* * *}$ \\
\hline & 10.-1. & - & $0.11 \%$ & (1.07) & $0.10 \%$ & $(0.92)$ \\
\hline
\end{tabular}

Note: Portfolio 1 contains the stocks with the lowest ESG value, while Portfolio 3 (or 10) contains the stocks with the highest ESG value. *** Significant at 1 per cent, ** at 5 per cent, * at 10 per cent.

\footnotetext{
${ }^{7}$ ENV results are also available on request.
} 
The Fama-MacBeth regressions show a weak but not significant relationship with a positive sign (Table 15). This indicates that there is indeed a noticeable difference between the longer and the newer, shorter period, but the relationship is not significant for the latter either. The results of the industry-related tests on groups are also consistent with those obtained so far, showing that the period breakdown also does not affect the main results (Table 16). Here, too, there is only a small shift in the positive direction. No significant returns are seen for any of the groups in either the tercile- or the decile-based sort.

\begin{tabular}{|c|c|c|}
\hline \multicolumn{3}{|c|}{$\begin{array}{l}\text { Table } 15 \\
\text { ESG and ENV, Fama-MacBeth regression (2013-2019, total market) }\end{array}$} \\
\hline Variable & 1 & 2 \\
\hline ESG & $\begin{array}{l}0.0016 \\
(1.21)\end{array}$ & - \\
\hline ENV & - & $\begin{array}{l}0.0011 \\
(1.37)\end{array}$ \\
\hline Beta & $\begin{array}{l}0.0088 \\
(0.05)\end{array}$ & $\begin{array}{l}-0.1160 \\
-(0.64)\end{array}$ \\
\hline Size & $\begin{array}{c}0.0928 \\
(2.93)^{* * *}\end{array}$ & $\begin{array}{c}0.0773 \\
(2.44)^{* *}\end{array}$ \\
\hline Btm & $\begin{array}{c}-0.1235 \\
-(3.87)^{* * *}\end{array}$ & $\begin{array}{l}-0.1029 \\
-(3.23)^{* * *}\end{array}$ \\
\hline Mom & $\begin{array}{l}-0.8806 \\
-(1.67)^{*}\end{array}$ & $\begin{array}{l}-0.4815 \\
-(1.21)\end{array}$ \\
\hline
\end{tabular}

Note: In the regressions, I explained returns by ESG or ENV as well as control variables, which are: market beta (Beta), market capitalisation (Size), book-to-market ratio (Btm) and momentum (Mom). The table shows the time-series mean of the coefficients $(x 100)$ as well as the corresponding Newey-West t-statistics in parentheses. *** Significant at 1 per cent, ** at 5 per cent, * at 10 per cent. 


\begin{tabular}{|c|c|c|c|c|c|c|}
\hline \multicolumn{7}{|l|}{$\begin{array}{l}\text { Table } 16 \\
\text { ESG, tercile }\end{array}$} \\
\hline & \multirow[b]{2}{*}{ Quantile } & \multirow[b]{2}{*}{ Mean ESG } & \multicolumn{2}{|c|}{ Equal-weighted portfolio } & \multicolumn{2}{|c|}{ Value-weighted portfolio } \\
\hline & & & Mean return & $\begin{array}{l}\text { Newey- } \\
\text { West t }\end{array}$ & Mean return & $\begin{array}{l}\text { Newey- } \\
\text { West t }\end{array}$ \\
\hline \multirow{4}{*}{$\begin{array}{l}\text { Very low }(28,55,58, \\
73,49)\end{array}$} & 1. & 18.81 & $0.54 \%$ & (1.30) & $0.53 \%$ & (1.29) \\
\hline & 2. & 31.92 & $0.65 \%$ & $(2.14)^{* *}$ & $0.66 \%$ & $(2.15)^{* *}$ \\
\hline & 3. & 58.78 & $0.58 \%$ & $(1.45)$ & $0.57 \%$ & $(1.43)$ \\
\hline & 3. -1 . & - & $0.04 \%$ & $(0.41)$ & $0.03 \%$ & $(0.35)$ \\
\hline \multirow[t]{4}{*}{ Low $(85,43,37,13,79)$} & 1. & 21.82 & $0.99 \%$ & $(3.38)^{* * *}$ & $0.99 \%$ & $(3.41)^{* * *}$ \\
\hline & 2. & 38.49 & $1.04 \%$ & $(3.57)^{* * *}$ & $1.04 \%$ & $(3.60)^{* * *}$ \\
\hline & 3. & 64.57 & $1.03 \%$ & $(3.11)^{* * *}$ & $1.04 \%$ & $(3.15)^{* * *}$ \\
\hline & $3 .-1$. & - & $0.04 \%$ & $(0.51)$ & $0.05 \%$ & $(0.55)$ \\
\hline \multirow{4}{*}{$\begin{array}{l}\text { Medium }(19,67,52,40 \text {, } \\
61)\end{array}$} & 1. & 23.37 & $1.01 \%$ & $(2.75)^{* * *}$ & $1.01 \%$ & $(2.78)^{* * *}$ \\
\hline & 2. & 43.90 & $0.88 \%$ & $(2.39)^{* *}$ & $0.88 \%$ & $(2.40)^{* *}$ \\
\hline & 3. & 68.96 & $0.90 \%$ & $(2.68)^{* * *}$ & $0.90 \%$ & $(2.71)^{* * *}$ \\
\hline & 3.-1. & - & $-0.10 \%$ & $-(0.64)$ & $-0.11 \%$ & $-(0.68)$ \\
\hline \multirow{4}{*}{$\begin{array}{l}\text { High }(64,25,82,70 \text {, } \\
\text { 16) }\end{array}$} & 1. & 25.84 & $0.91 \%$ & $(3.43)^{* * *}$ & $0.91 \%$ & $(3.41)^{* * *}$ \\
\hline & 2. & 47.98 & $0.93 \%$ & $(3.15)^{* * *}$ & $0.93 \%$ & $(3.17)^{* * *}$ \\
\hline & 3. & 71.94 & $0.98 \%$ & $(4.29) * * *$ & $0.98 \%$ & $(4.41)^{* * *}$ \\
\hline & $3 .-1$. & - & $0.07 \%$ & $(0.65)$ & $0.08 \%$ & $(0.70)$ \\
\hline \multirow{4}{*}{$\begin{array}{l}\text { Very high }(34,22,31 \text {, } \\
46,76)\end{array}$} & 1. & 30.22 & $1.04 \%$ & $(3.69) * * *$ & $1.03 \%$ & $(3.66)^{* * *}$ \\
\hline & 2. & 56.66 & $1.08 \%$ & $(5.11)^{* * *}$ & $1.08 \%$ & $(5.19)^{* * *}$ \\
\hline & 3. & 78.80 & $1.08 \%$ & $(5.06)^{* * *}$ & $1.08 \%$ & $(5.05)^{* * *}$ \\
\hline & 3. -1 . & - & $0.04 \%$ & $(0.24)$ & $0.04 \%$ & $(0.26)$ \\
\hline Very low & 10.-1. & - & $0.04 \%$ & $(0.27)$ & $-0.02 \%$ & $-(0.13)$ \\
\hline Low & 10.-1. & - & $0.16 \%$ & $(1.56)$ & $0.16 \%$ & (1.48) \\
\hline Medium & $10 .-1$. & - & $-0.08 \%$ & $-(0.29)$ & $-0.07 \%$ & $-(0.26)$ \\
\hline High & $10 .-1$. & - & $-0.04 \%$ & $-(0.24)$ & $-0.06 \%$ & $-(0.38)$ \\
\hline Very high & 10.-1. & - & $-0.13 \%$ & $-(0.51)$ & $-0.16 \%$ & $-(0.58)$ \\
\hline
\end{tabular}


The Fama-MacBeth regressions performed by industry grouping show a similar pattern as for the total market for the period 2013-2019 (Table 17). The previous significant negative relationship disappears, and a significant positive coefficient is observed for the group with a very low ESG value. However, the economic significance of this remains negligible (due to its size). Thus, there is no significant positive correlation between the ESG and the expected returns here either.

\begin{tabular}{|c|c|c|c|c|c|}
\hline Variable & 1 & 2 & 3 & 4 & 5 \\
\hline Very low & $\begin{array}{c}0.0029 \\
(2.29)^{* *}\end{array}$ & - & - & - & - \\
\hline Low & - & $\begin{array}{c}-0.0090 \\
-(0.45)\end{array}$ & - & - & - \\
\hline Medium & - & - & $\begin{array}{c}-0.0090 \\
-(0.33)\end{array}$ & - & - \\
\hline High & - & - & - & $\begin{array}{c}0.0006 \\
0.04\end{array}$ & - \\
\hline Very high & - & - & - & - & $\begin{array}{c}0.0037 \\
(0.87)\end{array}$ \\
\hline Beta & $\begin{array}{c}0.31 \\
(0.53)\end{array}$ & $\begin{array}{l}0.15 \\
(0.30)\end{array}$ & $\begin{array}{l}0.30 \\
(0.58)\end{array}$ & $\begin{array}{l}-0.19 \\
-(0.39)\end{array}$ & $\begin{array}{c}0.17 \\
(0.40)\end{array}$ \\
\hline Size & $\begin{array}{c}0.09 \\
(1.98)^{* *}\end{array}$ & $\begin{array}{c}0.10 \\
(3.67)^{* * *}\end{array}$ & $\begin{array}{c}0.05 \\
(1.27) \\
\end{array}$ & $\begin{array}{c}0.10 \\
(1.94)^{*}\end{array}$ & $\begin{array}{c}0.06 \\
(1.62) \\
\end{array}$ \\
\hline Btm & $\begin{array}{c}-0.25 \\
-(4.92)^{* * *}\end{array}$ & $\begin{array}{c}-0.18 \\
-(3.35)^{* * *}\end{array}$ & $\begin{array}{c}-0.35 \\
-(4.96)^{* * *}\end{array}$ & $\begin{array}{c}-0.24 \\
-(6.72)^{* * *}\end{array}$ & $\begin{array}{c}-0.21 \\
-(3.32)^{* * *}\end{array}$ \\
\hline Mom & $\begin{array}{c}0.04 \\
(0.11)\end{array}$ & $\begin{array}{l}-0.71 \\
-(1.57)\end{array}$ & $\begin{array}{l}-0.57 \\
-(1.25)\end{array}$ & $\begin{array}{c}-1.54 \\
-(2.92)^{* * *}\end{array}$ & $\begin{array}{c}-1.24 \\
-(2.55)^{* *}\end{array}$ \\
\hline
\end{tabular}

Note: In the regressions, I explained returns by ESG as well as control variables, which are: market beta (Beta), market capitalisation (Size), book-to-market ratio (Btm) and momentum (Mom). The table shows the time-series mean of the coefficients $(\times 100)$ as well as the corresponding Newey-West $t$-statistics in parentheses. *** Significant at 1 per cent, ${ }^{* *}$ at 5 per cent, * at 10 per cent.

Overall, there is some increase in the significance of ESG in the period 2013-2019, but its impact is still not significant. It can be assumed that if I were to shorten the period further towards the present day, then this impact would become stronger, but it is not advisable to look at a very short time horizon, because no reliable conclusions can be drawn based on a few years. The analysis of the period 2013-2019 therefore confirms what has been found so far; I reject the proposed hypotheses at this time horizon as well. 


\section{Conclusion}

To summarise the results of the tests: when we examine ESG in the total market, the returns of the portfolio creation are not significant, and the Fama-Macbeth regression suggests a weak negative relationship, which, however, cannot be considered economically significant. On this basis, the ESG rating for the total market does not carry additional value and is not yet priced. Similarly, when we examine ENV in the total market, the returns of the portfolio creation are clearly not significant, and the Fama-Macbeth regression suggests a weak negative relationship with negligible economic significance. This is consistent with what has been found so far. Thus, the environmental component does not carry investmentrelated abnormal return and is not priced. Based on this, I reject my hypothesis that investing in companies with responsible and sustainable management can result in higher profit than investing in companies that ignore these aspects.

Looking at ESG by industry breakdown, we see that the returns of the portfolio creation are not significant for most industries. The exceptions to this are 4 industries (textiles, tobacco, miscellaneous and automotive), where there is a significant negative relationship. None of them are environmentally friendly, and ESG is relatively low in each sector. The negative relationship may be due to the fact that in these industries, more 'irresponsible' behaviour is conducive to more profitable operations. Only in the apparel industry did I obtain significantly positive returns, which may be a very special industry characteristic or, with so many tests, a coincidence. Looking at ENV in a detailed industry breakdown, we see that the returns of the portfolio creation are not significant for most industries. The exceptions to this are 7 industries, namely textiles; tobacco; automotive; electrical; oil, gas and coal; diversified; and food, where there is a significant negative relationship. Again, the negative relationship may be due to the fact that in these industries, less environmentally-conscious behaviour is conducive to more profitable operations, an even stronger effect here than in the case of ESG. With regard to the apparel industry, the strategy also yields significant returns in this case, which is certainly an interesting result. As we have seen, Kumar et al. also concluded that industries could be relevant in evaluating responsible investments, so my results are consistent with those of the academic literature, but I reject the proposed hypothesis with respect to industry breakdown as well.

In the case of tests on groups, I did not obtain significant returns for either ESG or ENV, and the Fama-Macbeth regression indicated a weak negative relationship, which is stronger but still not significant in the extreme groups: such a grouping by score does not differ substantially from the analysis of the total market.

Based on the tests, the market may be sensitive to extreme values. To examine this, I used relative ESG and relative ENV score. The relative ESG and ENV tested by sort 
in the total market (similarly to the 'simple' indicators) are not significant in any of the cases. The Fama-Macbeth regression shows a weak negative relationship similar to what was found so far, which is insignificant in economic terms. In the 5-group industry analysis, the return was significant for the relative ESG only in the decilebased sort, in the very high group, and only at the 10 per cent significance level. Interestingly, when examining the relative ENV, it was the very low group where I obtained significant returns with both the tercile- and decile-based scales. The Fama-Macbeth regressions also give some indication of this, where I found a slightly stronger relationship for the extreme groups, but these results cannot be considered robust and can only be accepted at a high significance level; in fact, with so many tests, this may be a coincidence. All of these lead me to reject my hypothesis that profit can be increased if I apply different restrictions or relative scores.

Due to the sensitivity of the analysis and to confirm the robustness of the results, I also performed the major tests for a narrower time interval (2013-2019). Here again, a mechanism similar to that of the full period analysis can be seen. The results shift somewhat towards a positive relationship but are still not significant. On this basis, it remains true also for the more recent period that neither the ESG nor the ENV factor can be considered a significant forecaster of expected returns. Thus, we cannot expect higher profits from responsible and sustainable investments for the time being. The visible shift in the positive direction raises interesting questions about the potential for responsible and sustainable management to become increasingly significant, but this is not yet evident for the longer time horizon. Nevertheless, the topic could certainly be an interesting area for further research.

The negative relationship observed in some places is presumably due to the costs of responsible and sustainable management. This may result in less profitable operations, which may explain the slightly negative relationship. In the tests, the environmental component in itself does not differ basically from the total ESG. This means that environmental considerations are not of paramount significance. My results show that responsible and sustainable investment alone cannot generate higher profits, even under special constraints. One explanation for this may be the phenomenon of 'greenwashing', which refers to polluting, unsustainable companies trying to make themselves look good and thus achieve a higher ESG score. A further line of research could be the investigation of the exact impact of greenwashing. In further studies, it is worth comparing the markets of developed and developing countries as well. My results also show that the stocks of companies with high ESG or ENV score do not perform significantly worse than those with low score. This raises the possibility of further research as to what risk is associated with these returns and whether responsible and sustainable management can reduce the risk with the same return. My study can lay the groundwork for these further lines of research by demonstrating in detail that responsible and sustainable management does not result in significantly higher returns for investors. 


\section{References}

Amihud, Y. (2002): Illiquidity and stock returns: cross-section and time-series effects. Journal of Financial Markets, 5(1): 31-56. https://doi.org/10.1016/S1386-4181(01)00024-6

Aouadi, A. - Marsat, S. (2018): Do ESG controversies matter for firm value? Evidence from international data. Journal of Business Ethics, 151(4): 1027-1047. https://doi.org/10.1007/ s10551-016-3213-8

Auer, B.R. - Schuhmacher, F. (2016): Do socially (ir)responsible investments pay? New evidence from international ESG data. The Quarterly Review of Economics and Finance, 59(February): 51-62. https://doi.org/10.1016/j.qref.2015.07.002

Bakó, B. - Neszveda, G. - Dezső, L. (2018): When irrelevant alternatives do matter. The effect of focusing on loan decisions. Theory and Decision, 84(1): 123-141. https://doi. org/10.1007/s11238-017-9641-9

Bakó, B. - Neszveda, G. (2020): The Achilles' heel of Salience theory and a way to fix it. Economics Letters, 193, 109265. https://doi.org/10.1016/j.econlet.2020.109265

Bank, D. (2018): Implicit és explicit, valamint belső és külső CSR egy kettős függésben lévő piacgazdaságban. Különös tekintettel a munkavállalókról való gondoskodásra (Implicit and explicit, internal and external CSR in a double dependent market economy. Especially regarding labor provisions). Doctoral dissertation, Budapesti Corvinus Egyetem. https:// doi.org/10.14267/phd.2018009

Berlinger, E. - Walter, Gy. (1999): Faktormodellek az értékpapírpiacon (Factor models in the securities market). Bankszemle, 43(4): 34-43.

Bordalo, P. - Gennaioli, N. - Shleifer, A. (2013): Salience and consumer choice. Journal of Political Economy, 121(5): 803-843. https://doi.org/10.1086/673885

Bóta, G. (2014): A magyarországi befektetési alapok teljesítményét meghatározó tényezők vizsgálata (Determinants of the performance of investment funds managed in Hungary). Hitelintézeti Szemle, 13(2): 147-163. http://epa.oszk.hu/02700/02722/00071/pdf/ EPA02722_hitelintezeti_szemle_2014_2_147-163.pdf

Buallay, A. (2019): Is sustainability reporting (ESG) associated with performance? Evidence from the European banking sector. Management of Environmental Quality: An International Journal, 30(1): 98-115. https://doi.org/10.1108/MEQ-12-2017-0149

Cao, J. - Titman, S. - Zhan, X. - Zhang, W.E. (2020): ESG Preference, Institutional Trading, and Stock Return Patterns. Working Paper, National Bureau of Economic Research. https:// doi.org/10.3386/w28156 
Carhart, M.M. (1997): On persistence in mutual fund performance. The Journal of Finance, 52(1): 57-82. https://doi.org/10.1111/j.1540-6261.1997.tb03808.x

Csillag, B. - Neszveda, G. (2020): A gazdasági várakozások hatása a tőzsdei momentumstratégiára (The impact of economic expectations on the momentum trading strategy). Közgazdasági Szemle (Economic Review), 67(11): 1093-1111. http://doi. org/10.18414/KSZ.2020.11.1093

Deák, Zs. - Hajdu Istvánné (2011): Az élelmiszer-ipari vállalkozások környezeti teljesítménye és a pénzügyi eredmények (The environmental performance and financial results of food industry businesses). Gazdálkodás: Scientific Journal on Agricultural Economics, 55(7): 662-667. https://doi.org/10.22004/ag.econ.119945

Dorfleitner, G. - Halbritter, G. - Nguyen, M. (2015): Measuring the level and risk of corporate responsibility - An empirical comparison of different ESG rating approaches. Journal of Asset Management, 16(7): 450-466. https://doi.org/10.1057/jam.2015.31

Fain, M. - Naffa, H. (2019): Performance Measurement of Active Investment Strategies Using Pure Factor Portfolios. Financial and Economic Review, 18(2): 52-86. http://doi. org/10.33893/FER.18.2.5286

Fama, E.F. - French, K.R. (1992): The cross-section of expected stock returns. The Journal of Finance, 47(2): 427-465. https://doi.org/10.1111/j.1540-6261.1992.tb04398.x

Fama, E.F. - French, K.R. (1996): The CAPM is wanted, dead or alive. The Journal of Finance, 51(5): 1947-1958. https://doi.org/10.1111/j.1540-6261.1996.tb05233.x

Fama, E.F. - French, K.R. (2018): Choosing factors. Journal of Financial Economics, 128(2): 234-252. https://doi.org/10.1016/j.jfineco.2018.02.012

Fama, E.F. - MacBeth, J.D. (1973): Risk, return, and equilibrium: Empirical tests. Journal of Political Economy, 81(3): 607-636.

Fernandez, P. (2015): CAPM: an absurd model. Business Valuation Review, 34(1): 4-23. https://doi.org/10.5791/0882-2875-34.1.4

Gillan, S. - Hartzell, J. - Koch, A. - Starks, L.T. (2010): Firms' environmental, social and governance (ESG) choices, performance and managerial motivation. Unpublished working paper, Texas Tech University and University of Texas at Austin. http://www.pitt. edu/ awkoch/ESG\%20Nov\%202010.pdf. Downloaded: 15 September 2020.

Gloßner, S. (2017): ESG Risks and the Cross-Section of Stock Returns. Finance Meeting EUROFIDAI-AFFI, Paris, December. http://dx.doi.org/10.2139/ssrn.2980917

Golovics, J. (2015): Bounded rationality and altruism: behaviourism in economics. Financial and Economic Review, 14(2): 158-172. https://en-hitelintezetiszemle.mnb.hu/letoltes/6golovics-en.pdf 
Halbritter, G. - Dorfleitner, G. (2015): The wages of social responsibility - where are they? A critical review of ESG investing. Review of Financial Economics, 26(1): 25-35. https:// doi.org/10.1016/j.rfe.2015.03.004

Halldórsdóttir, T.R. (2020): Did firms with higher ESG ranking provide better stock performance during Covid-19? Doctoral dissertation, Reykjavik University. https://skemman.is/ handle/1946/37170?locale=en

Hassel, L.G. - Semenova, N. (2013): The Added Value of Environmental, Social and Governance Performance and Sustainable and Responsible Investment on Company and Portfolio Levels - What Can We Learn from Research? Working paper, Sustainable Investment Research Platform. https://www.researchgate.net/profile/Natalia-Semenova-2/publication/259452763_The_Added_Value_of_Environmental_Social_and_Governance_Performance_and_Sustainable_and_Responsible_Investment_on_Company_and_Portfolio_Levels_-_What_Can_We_Learn_from_Research/links/54bac5a20cf253b50e2d0608/ The-Added-Value-of-Environmental-Social-and-Governance-Performance-and-Sustainable-and-Responsible-Investment-on-Company-and-Portfolio-Levels-What-Can-We-Learnfrom-Research.pdf

Henke, H.M. (2016): The effect of social screening on bond mutual fund performance. Journal of Banking \& Finance, 67(June): 69-84. https://doi.org/10.1016/j.jbankfin.2016.01.010

Ince, O.S. - Porter, R.B. (2006): Individual equity return data from Thomson Datastream: Handle with care! Journal of Financial Research, 29(4): 463-479. https://doi.org/10.1111/ j.1475-6803.2006.00189.x

Jain, M. - Sharma, G.D. - Srivastava, M. (2019): Can Sustainable Investment Yield Better Financial Returns: A Comparative Study of ESG Indices and MSCI Indices. Risks, 7(1), 15. https://doi.org/10.3390/risks7010015

Khan, M. (2019): Corporate Governance, ESG, and Stock Returns around the World. Financial Analysts Journal, 75(4): 103-123. https://doi.org/10.1080/0015198X.2019.1654299

Kotsantonis, S. - Pinney, C. - Serafeim, G. (2016): ESG integration in investment management: Myths and realities. Journal of Applied Corporate Finance, 28(2): 10-16. https://doi. org/10.1111/jacf.12169

Kotsantonis, S. - Serafeim, G. (2019): Four Things No One Will Tell You About ESG Data. Journal of Applied Corporate Finance, 31(2): 50-58. https://doi.org/10.1111/jacf.12346

Kőszegi, B. - Szeidl, A. (2013): A Model of Focusing in Economic Choice. Quarterly Journal of Economics, 128(1): 53-104. https://doi.org/10.1093/qje/qjs049

Kumar, A. - Smith, C. - Badis, L. - Wang, N. - Ambrosy, P. - Tavares, R. (2016): ESG factors and risk-adjusted performance: a new quantitative model. Journal of Sustainable Finance \& Investment, 6(4): 292-300. https://doi.org/10.1080/20430795.2016.1234909 
Kumar, R. (2019): ESG: Alpha or Duty? The Journal of Index Investing, 9(4): 58-66. https:// doi.org/10.3905/jii.2019.1.066

Kuzmina, J. - Lindemane, M. (2017): ESG Investing: New Challenges and New Opportunities. Journal of Business Management, 5(14): 85-98

Lai, T.Y. - Stohs, M.H. (2015): Yes, CAPM is dead. International Journal of Business, 20(2): 144-158.

Landi, G. - Sciarelli, M. (2019): Towards a more ethical market: the impact of ESG rating on corporate financial performance. Social Responsibility Journal, 15(1): 11-27. https://doi. org/10.1108/SRJ-11-2017-0254

Li, F. - Polychronopoulos, A. (2020): What a difference an ESG ratings provider makes! Working Paper. https://www.researchaffiliates.com/en_us/publications/articles/what-adifference-an-esg-ratings-provider-makes.html. Downloaded: 17 January 2021.

Maiti, M. (2020): Is ESG the succeeding risk factor? Journal of Sustainable Finance \& Investment. https://doi.org/10.1080/20430795.2020.1723380

Mérő, B. - Nagy, O. - Neszveda, G. (2019): Új faktorok tesztelése az empirikus eszközárazásban (Testing new factors in empirical asset pricing). SZIGMA Matematikaiközgazdasági folyóirat (Journal of Mathematical Economics), 50(4): 263-281.

Németh-Durkó, E. (2019): Környezet és pénzügyek (Environment and Finance). Budapesti Corvinus Egyetem, Working Paper. http://unipub.lib.uni-corvinus.hu/4294/1/NDE_ kornyezet_es_penzugyek.pdf. Downloaded: 18 August 2020.

Neszveda, G. (2018): The Contribution of Thaler to Behavioural Economics. Financial and Economic Review, 17(1): 153-167. http://doi.org/10.25201/FER.17.1.153167

Newey, W.K. - West, K.D. (1987): Hypothesis Testing with Efficient Method of Moments Estimation. International Economic Review, 28(3): 777-787. https://doi. org $/ 10.2307 / 2526578$

Ransburg, B. - Vágási, M. (2011): A fenntartható fejlődés vállalati integrációja és kommunikációja - a hazai nagyvállalati gyakorlat vizsgálata (The Integration of Sustainable Development in the Light of Corporate Communication - The Case of Corporations in Hungary). Vezetéstudomány - Budapest Management Review, 42(10): 2-13. https://doi. org/10.14267/VEZTUD.2011.10.01

Ribando, J.M. - Bonne, G. (2010): A new quality factor: Finding alpha with ASSET4 ESG data. Starmine Research Note, Thomson Reuters, 31 March. https://www.thomsonreuters.com/ content/dam/openweb/documents/pdf/tr-com-financial/report/starmine-quant-researchnote-on-asset4-data.pdf 
Sahut, J.M. - Pasquini-Descomps, H. (2015): ESG Impact on Market Performance of Firms: International Evidence. Management International/International Management/Gestiòn Internacional, 19(2): 40-63. https://doi.org/10.7202/1030386ar

Shumway, T. (1997): The Delisting Bias in CRSP data. The Journal of Finance, 52(1): 327-340. https://doi.org/10.1111/j.1540-6261.1997.tb03818.x

Talan, G. - Sharma, G.D. (2019): Doing Well by Doing Good: A Systematic Review and Research Agenda for Sustainable Investment. Sustainability, 11(2), 353. https://doi. org/10.3390/su11020353

Torre, M.L. - Mango, F. - Cafaro, A. - Leo, S. (2020): Does the ESG Index Affect Stock Return? Evidence from the Eurostoxx50. Sustainability, 12(16), 6387. https://doi.org/10.3390/ su12166387

Townsend, B. (2020): From SRI to ESG: The Origins of Socially Responsible and Sustainable Investing. The Journal of Impact and ESG Investing, 1(1): 10-25. https://doi.org/10.3905/ jesg.2020.1.1.010

US SIF Foundation (2018): Report on US Sustainable, Responsible and Impact Investing Trends 2018. US SIF Foundation study. https://www.ussif.org/files/Trends/Trends\%202018\%20 executive\%20summary\%20FINAL.pdf

Uyar, A. - Karaman, A.S. - Kilic, M. (2020): Is corporate social responsibility reporting a tool of signaling or greenwashing? Evidence from the worldwide logistics sector. Journal of Cleaner Production, 253(April), 119997. https://doi.org/10.1016/j.jclepro.2020.119997

Van Duuren, E. - Plantinga, A. - Scholtens, B. (2016): ESG Integration and the Investment Management Process: Fundamental Investing Reinvented. Journal of Business Ethics, 138(3): 525-533. https://doi.org/10.1007/s10551-015-2610-8

Verheyden, T. - Eccles, R.G. - Feiner, A. (2016): ESG for all? The impact of ESG screening on return, risk, and diversification. Journal of Applied Corporate Finance, 28(2): 47-55. https://doi.org/10.1111/jacf.12174

Wimmer, M. (2013): ESG-persistence in Socially Responsible Mutual Funds. Journal of Management. \& Sustainability, 3(1): 9-15. http://dx.doi.org/10.5539/jms.v3n1p9

Yu, E.P.Y. - Van Luu, B. - Chen, C.H. (2020): Greenwashing in environmental, social and governance disclosures. Research in International Business and Finance, 52(April): 101192. https://doi.org/10.1016/j.ribaf.2020.101192 